\title{
Correlates of Migratory and Spatial Patterns of Fulani Herdsmen Settlements Within Ogbomoso Region, Nigeria
}

\author{
ABOLADE, O *ADIGUN F. O OLUNIRAN D.D ADETUNJI M.A \\ Department of Urban and Regional Planning, Faculty of Environmental Sciences \\ Ladoke Akintola University of Technology, PMB 4000, Ogbomoso, Oyo State Nigeria \\ *Corresponding Author
}

\begin{abstract}
Migration presents and remains a quandary for policy makers in Nigeria as a Result of cultural heterogeneity of the country. Consequently, an urgent consciousness of looming dangers attached to uncontrolled internal migration is crucial for nomadic development. The paper thus examines migratory and spatial patterns of nomads within Ogbomoso Region. The selection of nomadic settlement was determined using geographic coordinates and use of structured questionnaire as a means of data collection. Accidental sampling method was used to select ten Fulani settlements for focus group discussion. X, Y, Z coordinates was utilized for all identified Fulani settlements to analyse spatial pattern of nomadic Fulani settlement while six hundred and forty seven (647) residents of immediate native host communities were randomly selected based on the building population of the selected host communities for questionnaire administration. Content Analysis was employed to analyse reports of Focus Group Discussion while complete spatial randomness Index Analysis was used to determine the spatial pattern of nomadic Fulani Settlement. Likert Scale was used to analyse the perception of residents of host communities on factors contributing to nomadic Fulani migratory and spatial patterns in the study area. The findings revealed that Fulani's are becoming permanent settlers within the study area with their length of stay ranging from Thirty three (33) years to three (3) years. Also a clustered spatial pattern of nomadic Fulani Migratory as indicated by residents are easy land acquisition (MFI, 5.01\%) availability of grazing area (MFI,5 \%.01) good dairy market(MFI, 4.98) and peaceful environment (MFI, 9.93). The study recommends formulation of appropriate nomadic migration policies and establishment of Ogbomoso Nomadic Development Authority in order to enhance the development of the region through nomadic Fulani Migration
\end{abstract}

DOI: $10.7176 / \mathrm{JCSD} / 51-01$

Publication date:September $30^{\text {th }} 2019$

\section{1: Introduction and Background to the Study}

Nomadic cultures (like the Fulani migrants of Nigeria), unlike settled communities in pre-industrial and industrial eras have had to deal constantly with various aspects of migration. This includes economic, cultural and social aspects of their population movement (Rafis, 2013). For the Fulani nomads, the basic settlement concern is nearness to food resources for their animals in order to guarantee survival and the expansion of their herds. Consequently, they tend to live informally in jungles and settlements many kilometers away from other residents of the community. The implication is the exemption of such informal settlements from provision of social amenities such as good communication routes, planned and hygienic environment, electricity supply, safe drinking water and among others. However, no matter how Fulani settlements appear to be largely shaped by marginalization, the transformation of this ethnic livelihood is becoming bolder particularly within Ogbomoso region.

It could be argued that settlement pattern of Fulani nomads is metamorphosing as many Fulani nomads are escaping from the traditional nomadic forms and entering into agro-pastoralism, trade or other livelihood options as they choose to have it. By implication, this diversification of livelihood of Fulani nomads is a pointer to a growing informal economy and most likely a permanent migration type which is against traditional nomadic practice. Therefore, the neglect of Fulani nomadic settlements in formal city planning processes poses a future tragedy. In broader terms, issues surrounding Fulani nomadic settlement within Ogbomoso region is a challenge that is predominant in the absence of suitable migration policies and formal settlement policies that respond to such. How effectively those challenges are met will play a big part in determining how developed this region will be in the future.

Morakinyo et al (2012) among other researchers highlighted the problems of informal settlements to include poor environmental conditions, informal economy, illegal and unplanned settlements, health risks, overcrowding, and poverty among others. The past attempts on this subject are meticulous nonetheless the study of informal settlements requires a survey of both positive and negative impacts particularly for Fulani nomads within Ogbomoso region so as to provide better insight on peculiarities of nomadic settlements. Furthermore, several Nigerian authors have analyzed issues relating to Fulani nomads. Authors like Olayoku (2014) and Isah (2014) are basically concerned with conflicts, violence and other crime issues emanating from the activities of Fulani nomads, neglecting the roles of planning in provision of their basic settlement needs. The opinions of Huchzermeyer (2004) and Kramer (2006), reveals that informal settlement is an attribute of urban areas coming 
up as spatial manifestation of rural-urban migration. However Fulani nomadic settlement is highly concentrated in the rural parts of Ogbomoso Region with few of population within the urban parts. Thus, the paper examines the impacts of Fulani Informal Settlements across Ogbomoso region encompassing both the rural and urban parts of the region.

\section{1: Method and Materials}

The study focused on Ogbomoso Region. It covers all the five Local Government Areas of the Region. The interests are on Fulani nomadic settlements and residents of their host communities. With particular concern on those Fulani nomadic settlement that are enclaves of settled members of Fulani ethnic group within Ogbomoso Region. All the Fulani settlements within the region is presented in Table 1 and further Illustrated Figure 1.

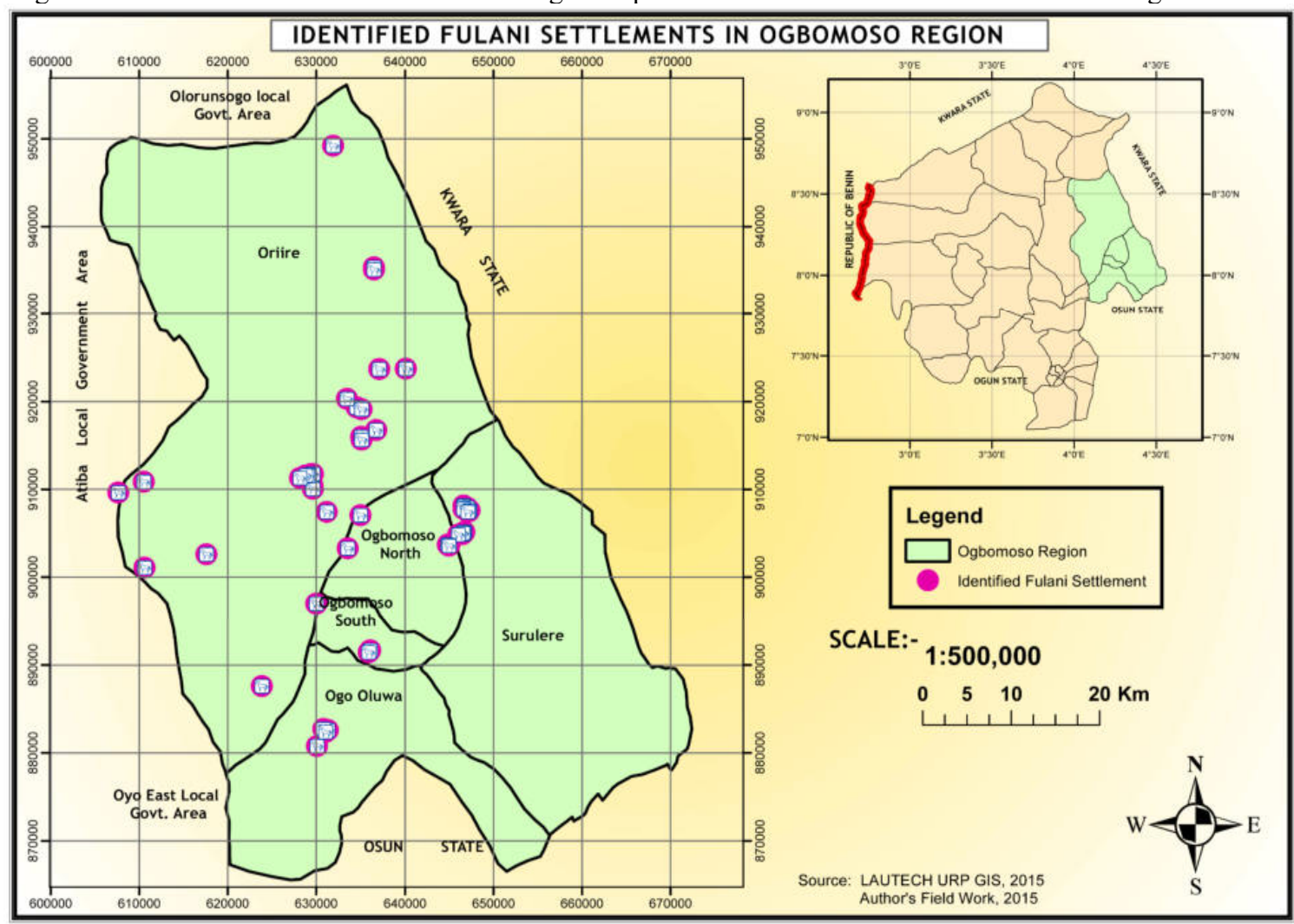

Figure 1 Fulani Settlements in Ogbomoso Region Source. Authors Field Survey 2015 
Table 1: Names of Local Governments and Identified Fulani Settlements in Each Host Community

\begin{tabular}{|c|c|c|c|}
\hline $\mathbf{S} / \mathbf{N}$ & $\begin{array}{c}\text { Local } \\
\text { Government } \\
\text { Area } \\
\end{array}$ & Host Community & Name of Identified Fulani Settlements \\
\hline 1 & $\begin{array}{l}\text { Ogbomoso } \\
\text { North }\end{array}$ & $\begin{array}{l}\text { Aaje-Ikose area } \\
\text { Iyana Olomi area }\end{array}$ & $\begin{array}{l}\text { Gaa Aaje-ikose } \\
\text { Gaa Iyana Olomi }\end{array}$ \\
\hline 2 & $\begin{array}{l}\text { Ogbomoso } \\
\text { South }\end{array}$ & $\begin{array}{l}\text { Iletitun Area } \\
\text { Ibapon Area } \\
\text { Owode Area } \\
\text { Abede Area }\end{array}$ & $\begin{array}{l}\text { Gaa Alimi, Gaa Ibrahim } \\
\text { Gaa alayun, Gaa Mohamodu. } \\
\text { Gaa owode } \\
\text { Gaa abede }\end{array}$ \\
\hline 3 & Orire & $\begin{array}{l}\text { Ajinapa } \\
\text { Tewure } \\
\text { Yawota Area }\end{array}$ & $\begin{array}{l}\text { Gaa ilomo } \\
\text { Gaa Tewure } \\
\text { Gaa Yawota Area }\end{array}$ \\
\hline 4 & Ogooluwa & $\begin{array}{l}\text { Olorunda Area } \\
\text { Esa-De Area } \\
\text { Alahausa Oloye } \\
\text { Area } \\
\text { Oguro-ologunrun } \\
\text { area } \\
\text { Ojotaye Area }\end{array}$ & $\begin{array}{l}\text { Gaa Olorunda } \\
\text { Gaa Esa-dee } \\
\text { Gaa Abanda } \\
\text { Gaa Keji, Gaa Olounda, Gaa Oke-high school. } \\
\text { Gaa Baba Fatimo, Gaa Tunde. }\end{array}$ \\
\hline 5 & Surulere & $\begin{array}{l}\text { Ojotaye Area } \\
\text { Babu Area } \\
\text { Maya Area } \\
\text { Iyelu I Area } \\
\text { Balogun Area } \\
\text { Iyelu II Area } \\
\text { Onipaanu Area } \\
\text { Iregba Area } \\
\text { Iresadu Area } \\
\text { Elegbodo Area }\end{array}$ & $\begin{array}{l}\text { Gaa Bello, Gaa Oja-nla, Gaa Sanda, Gaa Jumbo. } \\
\text { Gaa Obo-owo } \\
\text { Gaa Isa-agba, Gaa Isa-kerere. } \\
\text { Gaa Oni-Dusi, Gaa 'Laege, Gaa Arolu, Gaa ijado, Gaa alako. } \\
\text { Gaa Oseni } \\
\text { Gaa Alfa Hameed, Gaa Dotio, Gaa Elesun, Gaa Mumini, Gaa } \\
\text { Duro, Gaa Shereki. } \\
\text { Gaa Idi-Ya, Gaa Keewo, Gaa Idi-Apa, Gaa Oke-ogbe, Gaa abule- } \\
\text { Johnu. } \\
\text { Gaa Egbe } \\
\text { Gaa olokiti, Gaa Agayan. } \\
\text { Gaa Jimoh }\end{array}$ \\
\hline
\end{tabular}

Source: Author's Computation, 2015

The study employed random sampling method for administration of copies of structured questionnaire to residents of selected host communities while, purposive sampling method was utilized to select the Fulani nomadic settlements for Focus Group Discussion (FGD). The inventory of Fulani nomadic settlements indicated forty-seven (47) settlements across the study area. This was compiled from information given by Surulere Local Government Area Fulani Nomads Association, Ogbomoso Farmers Association and Ogbomoso South Local Government Area Cassava Farmers Association. The immediate native communities to all identified Fulani nomadic settlements are regarded as host communities. Meanwhile, for this study, five host communities from the urban parts of the study area and five host communities from the rural part of the study area were sampled in order to analyze variations in the impacts of Fulani nomadic settlements across urban-rural interphase (see Table 1). However, the housing stock of selected host communities was obtained either through direct counting or estimates given by the community leaders. Based on this, a total number of six hundred and forty-seven (647) residents across the selected host communities were randomly selected for questionnaire administration (see Table 2). On the other hand, one Fulani settlement was sampled in each host community in order to enhance objectivity of data collection. In each of the selected Fulani settlement, interview was conducted with the head of the clan. In case the clan head is not available, an adult was interviewed while the focus group discussion served as general platform for all available Fulani's.

Content analysis was employed to analyze the migratory pattern, land acquisition practice, socio-cultural needs and challenges of Fulani nomads in the study area. The method used the thematic approach to analyze such qualitative information as socio-economic characteristics, housing characteristics among other relevant information. For further analysis, one-way analysis of variance (ANOVA) was employed to show variation of various impacts of Fulani nomadic settlement on host communities within Ogbomoso region while Pearson Product Correlation Coefficient was be used to verify the relationship between increase in Fulani crime incidence and Fulani nomadic settlements. Descriptive statistics such as cross tabulation, averages and frequency counts were utilized to present the socio-economic characteristics of respondents. 
Table 2: Selected Fulani Settlements in Each Host Community

\begin{tabular}{|c|c|c|c|c|c|}
\hline$\overline{\mathbf{S} / \mathbf{N}}$ & $\begin{array}{l}\text { Local } \\
\text { Government } \\
\text { Area }\end{array}$ & $\begin{array}{l}\text { Host } \\
\text { Community }\end{array}$ & $\begin{array}{l}\text { Name of Selected } \\
\text { Fulani Settlements }\end{array}$ & $\begin{array}{l}\text { Estimated } \\
\text { Number } \\
\text { Buildings }\end{array}$ & $\begin{array}{l}\text { Number of } \\
\text { Questionnaires } \\
(\mathbf{2 0} \%)\end{array}$ \\
\hline \multirow[t]{2}{*}{1} & \multirow[t]{2}{*}{ Ogbomoso North } & Aaje-Ikose area & Gaa Bororo & 521 & 105 \\
\hline & & Iyana Olomi area & Gaa Iyana Olomi & 18 & 4 \\
\hline \multirow[t]{2}{*}{2} & \multirow[t]{2}{*}{ Ogbomoso South } & Iletitun Area & Gaa Omotunde & 42 & 9 \\
\hline & & Ibapon Area & Gaa Ibapon & 96 & 19 \\
\hline \multirow[t]{2}{*}{3} & \multirow[t]{2}{*}{ Orire } & Ajinapa & Gaa Alaya I & 496 & 99 \\
\hline & & Tewure & Gaa Ilomo & 1928 & 386 \\
\hline \multirow[t]{2}{*}{4} & Ogooluwa & Otamokun area & Gaa Otamokun & 27 & 5 \\
\hline & & $\begin{array}{l}\text { Oguro-ologunrun } \\
\text { area }\end{array}$ & Gaa Oguro & 45 & 9 \\
\hline \multirow[t]{3}{*}{5} & \multirow[t]{2}{*}{ Surulere } & Iyelu I Area & Gaa Akorede & 30 & 6 \\
\hline & & Onipaanu Area & Gaa Alata II. & 25 & 5 \\
\hline & Total & 10 & 10 & 3228 & 647 \\
\hline
\end{tabular}

Source: Author's Computation, 2015

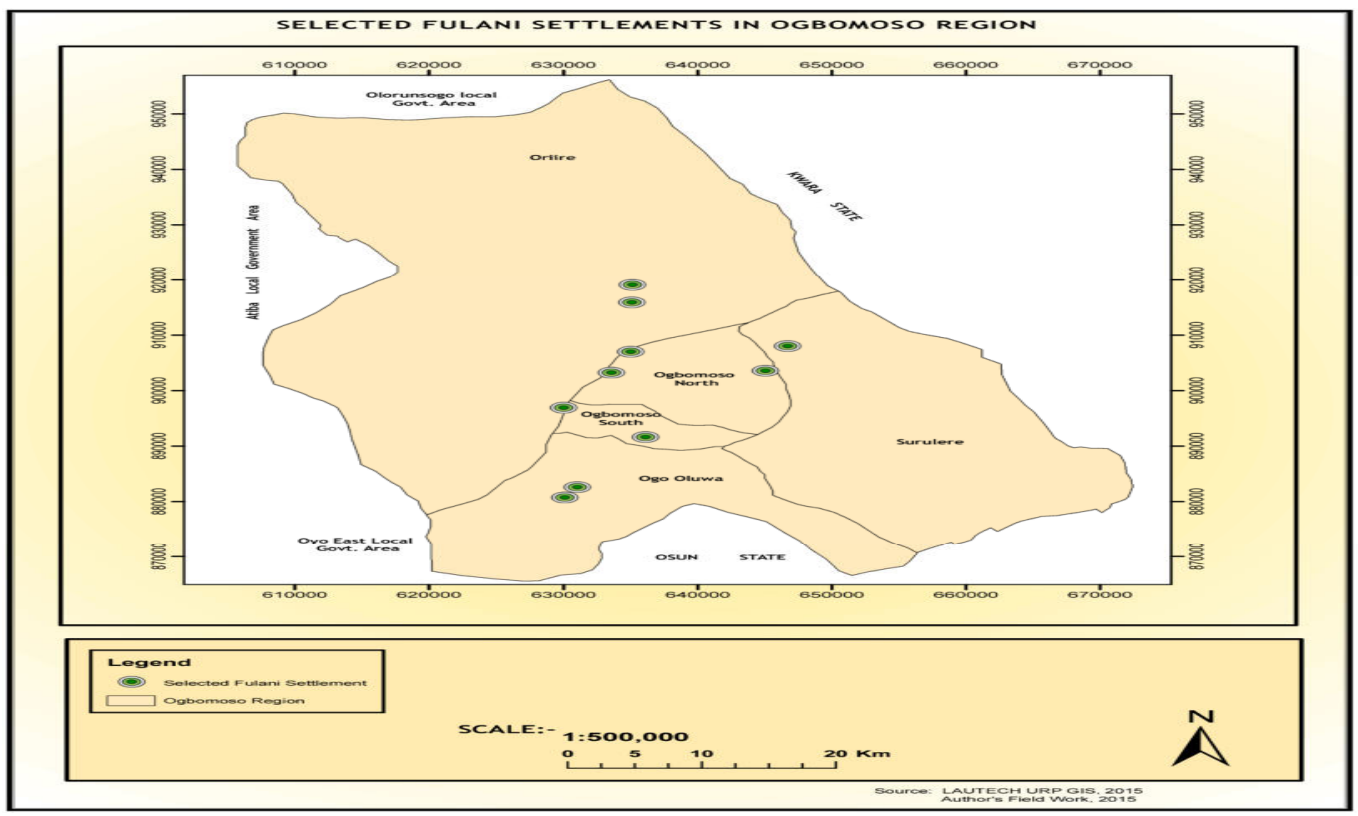

Figure 2 Selected Fulani Settlements in Ogbomoso Region

Source: Author's Compilation, 2015

\section{3: Results and Discussion of Findings}

\section{1: Migration Type of Fulani Nomads within Ogbomoso Region}

Khandeker (2011) identified two types of migration - permanent and semi-permanent in urban Bangladesh. However, in this study area, more than three types of migration relating to Fulani nomads are revealed. As shown in Figure 4.1, these are: semi-permanent type of migration is the most dominant (61.1\%) while some nomads $(20.9 \%)$ are permanent migrants and fewer proportions $(17.2 \%)$ are temporal type of migration. The least percentage of 0.8 recorded for other type of migration is cyclical migration (the constant outgoing and incoming of nomads within and outside the same area). This result suggests the Fulanis being nomads settle in the study area mostly on a semi-permanent basis and have more permanent settlers among them than temporal settlers. This is contrary to the common belief that Fulani nomads are mostly wanderers as in ancient times.

Furthermore, the interview conducted with different Fulani clan heads at Gaa Alaya II, Gaa Baba Biodun and Gaa Otamokun revealed that the period of stay within the study area rages from 33 years, 22 years and 3 years, respectively. Similarly, majority of Fulani nomads sampled, disclosed that their origin is mainly from Northern and Middle Belt parts of the country except one of the nomads who claimed to be a native of Ikoyi- ile, Ogbomoso, Oyo state. This could be corroborated with the assertion of Suleiman (2014) that Fulani herdsmen 
are predominant nomadic sect of the Northern part of Nigeria, who in search of pasture grass and water for their cattle, move from the north to the middle belt and some to the southern parts of the country. Also, all nomads sampled acknowledged that Ogbomoso region satisfied their search for green pastures for their cattle and

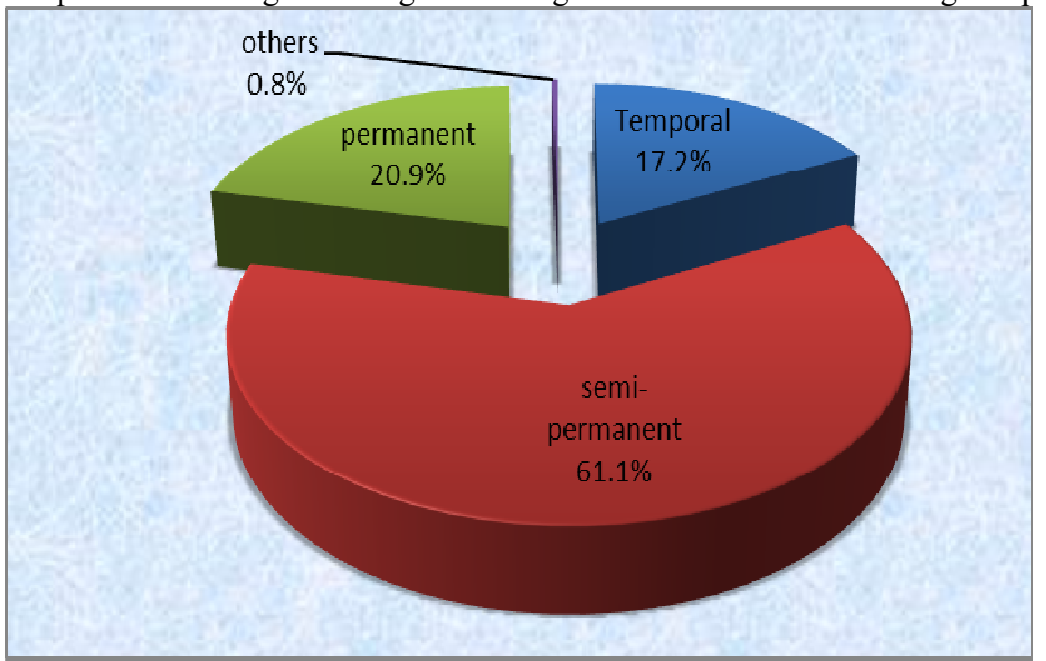

Figure 3 Migration Types of Fulani Nomads in Ogbomoso Region Source: Author's Fieldwork, 2015

\section{2: Migration Season and Settlement Process of Fulani Nomads in Ogbomoso Region}

Migration based on weather variations (seasons) is common within nomadic circles globally. Similarly, for Fulani nomads in Ogbomso Region migration is a seasonal phenonmenon. For instance, Figure 4 illustrates extremely low response $(0.6 \%)$ to dry season migration while larger percentage of responses $(38.3 \%)$ was made for all year season migration with the responses of residents who are not aware of migration season taking the largest of all (61.1\%). This finding is a typical scenario of internal migration in Nigeria where different people move in and out of a community and nobody cares about the movement not even other residents of the community. This conforms with the opinion of Oyesiku (2003) that Nigeria currently lacks any coordinated policy on internal migration that can ensure that the nation harnesses the potentials (both positive and negative) inherent in internal migration.

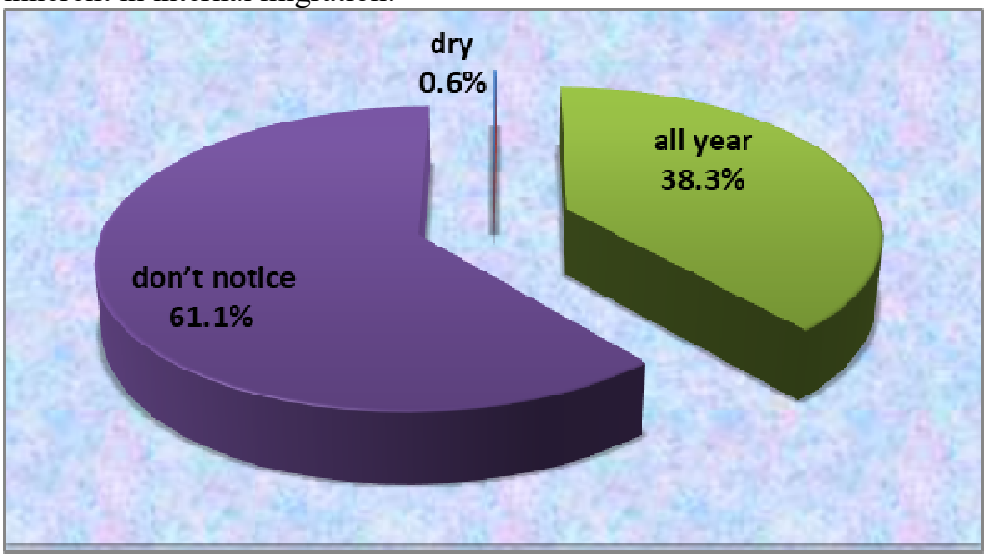

\section{Figure 4: Seasons of Migration of Fulani Nomads in Ogbomoso Region}

Source: Author's Fieldwork, 2015

Furthermore, the discrepancy in migration patterns and seasons of migration is a major underlying factor to different Fulani settlement process. Consequent to this, and from the result of analysis as illustrated in Figure 4 majority of the nomads $(50 \%)$ have not changed their settlement since their arrival to the study area. By implication, there is probability that most Nomads are contended with the space they settled since their arrival in Ogbomoso Region. However, $31 \%$ nomads had relocated their settlements to other places even within the study area while only $18 \%$ had abandoned their settlement completely whether for other place within or beyond the study area. On the other hand, on the question of eviction, this had least response (1.\%) as the environment is peaceful, providing or meeting the basic needs of nomads. It therefore implies that the environment has provided large expanse of land for grazing and farming and residents of host communities have being very friendly to the 
nomads, making a forceful ejection the least settlement process.

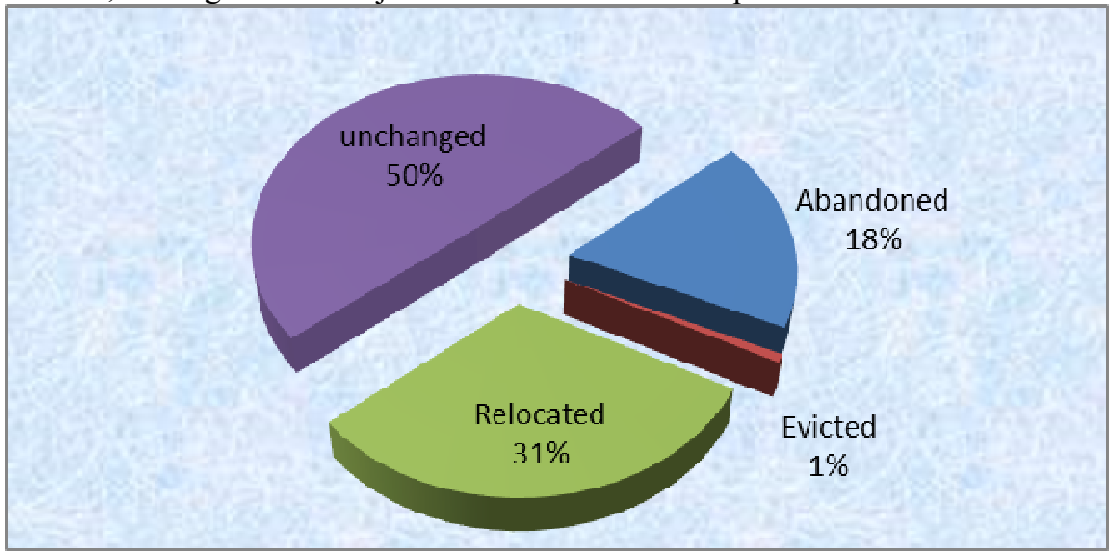

Figure 5 : Fulani Nomads Settlement Process in Ogbomoso Region

Source: Author's Fieldwork, 2015

3.3: Perceived Factors Contributing to the Migratory Pattern of Fulani Nomads within Ogbomoso Region Residents' views on factors contributing to migratory pattern of Fulani nomads in study area were summarized in Table 4.1 using the Likert Scales of "Very High", "High", "Indifferent", "Low" and "Very Low". This was rated 5,4,3,2, and 1 respectively. For adequate description of these factors, the highness of each was weighted through an index tagged Migratory Factor Index (MFI).

Table 3 presents an analysis that easy land acquisition and large land area for grazing recorded the highest indices of 5.01 each. This implies the two factors are the most important determinants of the migratory pattern of Fulani Nomads in the study area.

Similarly, a report given by one the nomads at Gaa Ibapon expressed that

"The land was legally and freely acquired from Ibapon family of Ogbomoso who claimed to be historically Fulanis as well.So this wide space you see, I was given free without paying a dime. The soil is good and yield enough grass for the cattle.Not only that, I am also a farmer that grows garden egg in large scale, the soil is fertile for that too and this place is very accessible to transport my farm produce to the market".

Also, Table3 further revealed that good diary market as another factor with high MFI 4.98 while a Fulani woman at Gaa Otamokun also affirmed that "Apart from cattle rearing, the sales of dairy product are good then we enjoy the hospitality of the host community". It could be inferred from the above, that dairy products like cow milk and cheese are well accepted and consumed by the residents of the host communities. This is not surprising since dairy products from Fulanis are very affordable and are also good source of protein.

Further analysis, revealed that variables like good climatic conditions and adequate facilities have low perception MFI 4.62 and 2.98 respectively. These also have low deviations around the mean (4.63). The computed standard deviations was 0.6852 at a variance of 0.4695 and coefficient standard deviation of $34.3 \%$.

Based on this, it could be argued generally that availability or adequacy of facilities like good roads, health center, electricity, water supply, telecommunication and schools do not influence the migratory pattern of Fulani Nomads in the study area.

Table 3: Factors Contributing to the Migratory Pattern of Fulani Nomads within the Study Area

\begin{tabular}{|c|c|c|c|c|c|c|c|c|c|c|}
\hline \multirow[t]{2}{*}{ Factors of Migratory Pattern } & VH & $\mathbf{H}$ & IN & $\mathbf{L}$ & $\mathbf{V L}$ & \multirow[t]{2}{*}{ SWV } & \multirow[t]{2}{*}{$\mathbf{X}$} & \multirow[t]{2}{*}{ MFI } & \multirow[t]{2}{*}{ D } & \multirow[t]{2}{*}{$\mathbf{D}^{2}$} \\
\hline & 5 & 4 & 3 & 2 & 1 & & & & & \\
\hline Easy Land Acquisition & 643 & 04 & - & - & - & 3,239 & & 5.01 & 0.38 & 0.1444 \\
\hline $\begin{array}{l}\text { Large Land Area For } \\
\text { Grazing }\end{array}$ & 643 & 04 & - & - & - & 3,239 & & 5.01 & 0.38 & 0.1444 \\
\hline Good Dairy Market & 635 & 11 & 3 & - & - & 3,222 & 4.63 & 4.98 & 0.35 & 0.1225 \\
\hline Peaceful Environment & 600 & 47 & - & - & - & 3,188 & & 4.93 & 0.30 & 0.0900 \\
\hline Good Cattle Market & 585 & 55 & 3 & 2 & - & 3,160 & & 4.88 & 0.25 & 0.0625 \\
\hline Good Climatic Conditions & 400 & 247 & - & - & - & 2,988 & & 4.62 & -0.01 & 0.0001 \\
\hline Adequate Facilities & 185 & 13 & 56 & 393 & - & 1931 & & 2.98 & -1.65 & 2.7225 \\
\hline
\end{tabular}

Source: Author's Fieldwork, 2015

3.4:Spatial Pattern of Fulani Nomadic settlements within Ogbomoso Region

In this sub-section, the study appraises the spatial pattern of Fulani nomadic settlements, using Nearest 
Neighbour Analysis. The process involves plotting X,Y and Z coordinates of all identified Fulani nomadic settlements in the study area on a three-dimensional surface mapping package (Surfer 8). The essence of this is to determine the value of complete spatial randomness and the implication (s) of the same.

The summary of Nearest Neighbour Grid presented in Table 4. revealed the Rn value of 0.9884 for computed coordinates of all identified Fulani settlements in the study area. This suggests clustering of Fulani nomadic settlements within Ogbomoso region. The complete spatial randomness analysis also confirmed the clustering of the nomadic settlements with Clark and Evans aggregation index of 0.421784608968 (see Table 4.1). The clustered settlement pattern of Fulani settlements can facilitate spatial planning and facilities distribution in Fulani nomadic settlements. Further analysis shows standard deviation value (Delta $Z$ ) of 10.4201620802 and coefficient of variation value (Delta $Z$ ) of 1.47177430511 . The wide deviation suggests that the observed average distance of each Fulani settlements are scattered about the mean.

Table 4: Nearest Neighbour Analysis of Fulani Nomadic settlements within Ogbomoso Region

\begin{tabular}{lll}
\hline Grids & Separation Value & Delta Z Value \\
\hline Minimum & 0.000376563407675 & 0 \\
$\mathbf{2 5 \% - t i l e ~}$ & 0.000960416576283 & 1 \\
Midrange & 0.0662514794769 & 21.75 \\
$\mathbf{5 0 \% - t i l e ~}$ & 0.00250319795462 & 2.3 \\
$\mathbf{7 5 \% - t i l e ~}$ & 0.0133206381229 & 5 \\
Maximum & 0.132126395546 & 43.5 \\
Mean & 0.0134209651084 & 7.08 \\
Median & 0.00250319795462 & 2.3 \\
Standard Deviation & 0.0249185258525 & 10.4201620802 \\
Standard Error & 0.00336001334051 & 1.40505436826 \\
Sum Absolute & 0.738153080964 & 389.4 \\
Sum Squares & 0.043437105 & 8620.26 \\
Mean Square & 0.000789765545455 & 156.732 \\
Coefficient of Variation & 1.85668658335 & 1.47177430511 \\
Skewness & 2.71918296783 & 1.91042505361 \\
Kurtosis: & 11.1980995822 & 5.9615158187 \\
& Rn & $\mathbf{0 . 9 8 8 4}$ \\
\end{tabular}

Source: Author's Fieldwork, 2015

\section{5: Fulani Nomads' Land Acquisition Type within Ogbomoso Region}

Operationally, acquisition of land in Nigeria is recognized either by Land Use Act of 1978 (statutory law) or the custom of an area (customary law). Any of these describes land acquisition and ownership status. Land can be acquired by purchase, lease, bequeath, gift or rent.

The result of analysis as presented in Figure 6 shows that land acquisition type by the nomads is mostly through lease or purchase, each of this accounted for $45 \%$ respectively. Although, some (9\%) illegal land acquisition without following formal procedure were also recorded in the study area, however just $1 \%$ of the sampled proportion acquired their land by gift. This may be substantiated with a comment of one Fulani nomad who claimed that" the leasehold of our space is been renewed with farm produce and cattle as deem fit by us to give to the Olugbon (the sovereign Yoruba monarch around here)." Therefore, a fact can be established that land acquisition of Fulani nomads is mostly legally upheld by customary law. The implication centers on land administration and land use planning. Similarly, Wilbard and Volker (2001) posited that illegality notion that is often used by bureaucrats and policy makers to question the legal status of informal settlements is a misconception about the mechanisms and norms underlying informal housing land acquisition, security of tenure and subsequent settlement development. 


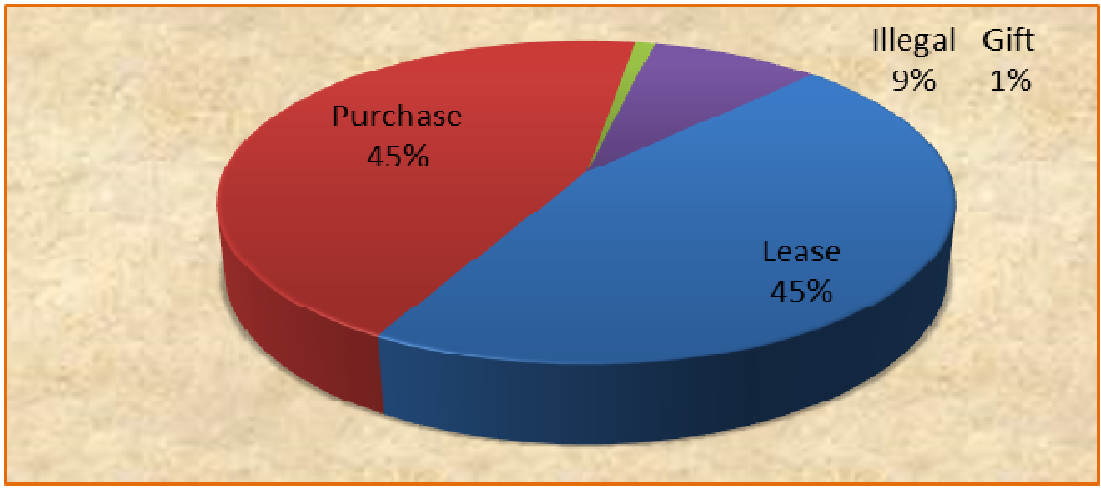

Figure 6: Fulani Nomads' Land Acquisition Type

Source: Author's Fieldwork, 2015

\section{6 : The Proximity of Fulani Informal Settlements to Communities and Farmlands}

Figure 7 presents the proximity range of Fulani nomadic settlements to communities and farmlands. For the former, many settlements are located between 1-2 kilometers (44.5\%) followed by those found at less than 1 kilometer $(37.4 \%)$ while fewer number of settlements are found 3-4 kilometers range (18.2\%) while for the latter, most settlements are located less than 1 kilometer (45.7\%) this is followed by settlements within 3-4 kilometers $(41.1 \%)$ but fewer settlements are located between 1-2 kilometers (13.2\%). The result of analysis above reveals that farthest distance between Fulani nomadic settlements to host communities and their farmlands is between 3-4 kilometers which could be referred as range as explained in Central Place Theory of Walter Christaller (1933). Adopting the theory, it could be inferred that this range between Fulani nomadic settlements, communities and farmlands is the determinant of low order marketing, transportation and administrative principles obtainable.

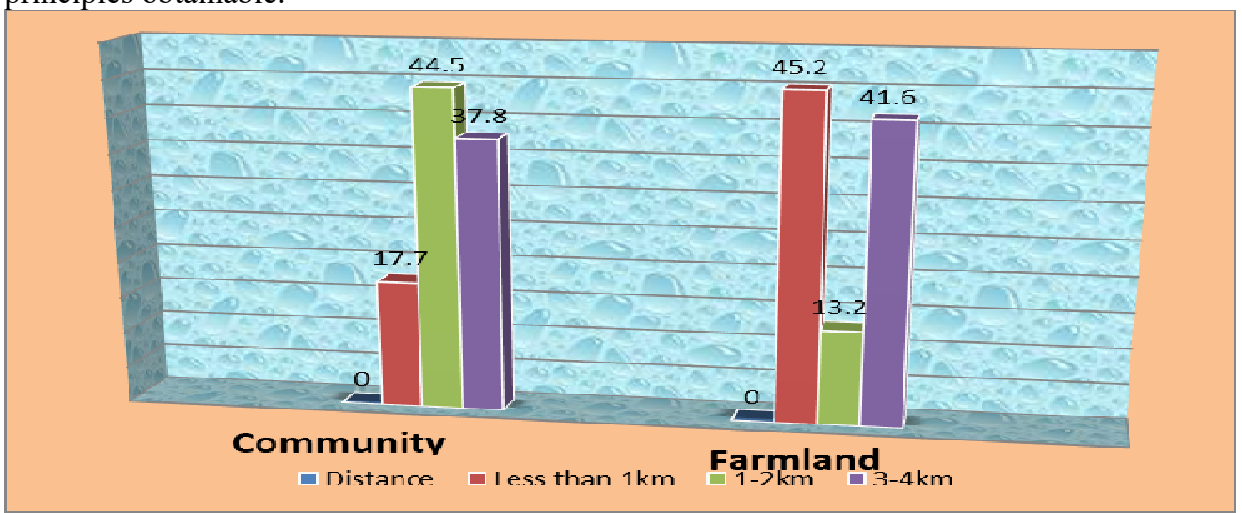

Figure 2: The Proximity of Fulani Informal Settlements to Communities and Farmlands Source: Author's Fieldwork, 2015

\section{7 : The Biophysical Impacts of Fulani Informal settlements}

Most human activities cannot be divorced from adverse environmental impacts. The key concern for ecological and human health includes atmospheric pollution, contamination of water resources and land pollution. Consequently, in the study area, impacts of pastoral activities of Fulani nomads on land, water and air are examined based on the perception of residents of host communities.

Likhert rating was utilized on a scale of 'very significant', 'significant' 'indifferent', 'not significant' and 'not at all' corresponding to either the weight of 5,4, 3,2 or 1 accordingly. An index developed to measure this was tagged Biophysical Impact Index (BII). However, the summary in Table 5 confirms grazing cattle destroying crops (BII, 2.73) and overgrazing of land (BII 2.72) as acute impacts of these nomads on land while cattle dung adding manure to the soil (BII, 2.28) is rather not a significant impact in the study area. This situation of overgrazing could have long term effects such as soil infertility, erosion, flood, drought, land gradation, desertification and climate change. Dregne et al (1991) emphasized that consumption of plant cover by livestock has a major impact and overgrazing is believed to contribute substantially to desertification and land degradation.

It is also observed that burning of surrounding bushes (BII, 2.69) is another significant biophysical impact both on land and air quality. According to Jamala et al (2012), Fulani nomads habitually use moderate, localized 
fires to fight ticks, insects, and harmful pests from the homes and kraals. Table 3 further revealed that water pollution through cattle dung polluting nearest water bodies to host communities (BII, 1.49) or cattle drinking from nearest river to host communities ( BII, 1.43) are perceived as less significant biophysical impacts of settlement of Fulani nomads in the study area. There is probability that this perception is influenced as a result of reasons like many residents of host communities not using water from unprotected sources like rivers, streams or ponds. Also, it can be observed in Table 1 that unpleasant smell from cattle dung is the least perceived environmental impact with BII of 1.99. The possibility of such perception could be based on the fact that Fulani Settlements are located few kilometers away from the immediate host communities reducing the diffusion of any unpleasant smell from such settlements. However, the recorded standard deviation was 0.5617 while the variance was 0.3155 and coefficient standard deviation was $28 \%$. The standard deviation suggests that distribution scatters about the mean value.

Table 5: The Biophysical Impacts of Fulani Nomadic settlements

\begin{tabular}{|c|c|c|c|c|c|c|c|c|c|c|}
\hline \multirow[t]{2}{*}{ Biophysical Impacts } & VS & $\mathbf{S}$ & IN & NS & NAA & SWV & BII & \multirow[t]{2}{*}{$\mathbf{X}$} & \multirow[t]{2}{*}{$\mathbf{D}$} & \multirow[t]{2}{*}{$\overline{\mathbf{D}^{2}}$} \\
\hline & 5 & 4 & 3 & 2 & 1 & & & & & \\
\hline $\begin{array}{l}\text { Cattle grazing on farmland } \\
\text { destroying the crops }\end{array}$ & 538 & 44 & & 65 & & 1767 & 2.73 & & 0.54 & 0.2916 \\
\hline Overgrazing of land & 538 & 43 & & 66 & & 1766 & 2.72 & & 0.53 & 0.2809 \\
\hline Burning of surrounding bushes & 538 & 22 & & 87 & & 1745 & 2.69 & & 0.5 & 0.2500 \\
\hline $\begin{array}{l}\text { Cattle dung adding manure to the } \\
\text { soil }\end{array}$ & 292 & 244 & & 111 & & 1475 & 2.28 & & 0.09 & 0.0081 \\
\hline $\begin{array}{l}\text { Cattle dung producing unpleasant } \\
\text { smell }\end{array}$ & 1 & 646 & & - & & 1293 & 1.99 & & -0.2 & 0.4000 \\
\hline $\begin{array}{l}\text { Cattle dung polluting nearest river to } \\
\text { your community }\end{array}$ & 1 & 646 & & - & & 1293 & 1.99 & & -0.2 & 0.4000 \\
\hline $\begin{array}{l}\text { Cattle drinking from river renders it } \\
\text { unfit for domestic purpose }\end{array}$ & 14 & 250 & & 383 & & 925 & 1.43 & & $-\overline{0}-76$ & 0.5776 \\
\hline
\end{tabular}

Source: Author's Fieldwork, 2015

\section{8: Impacts of Air and Green Spaces}

Although, Fulani structures are often clustered within a settlement yet adequate air space is maintained in all Fulani settlements coupled with presence of greeneries around their settlements. These are indicators to good environmental quality. Observations on location of Fulani Settlements within the study area revealed that majority of them are located in jungles, many meters away from the host communities in order to keep their animals away from intruding peoples' properties. Futhermore, such area provide large land area for animal grazing and developing settlements. Consequently, the settlements are well spaced (Plate 1 and 2) giving adequate air space between buildings and surrounded with beautiful vista of trees and grass Figure (Plate 1 and 2). The presence of adequate air and green spaces within Fulani settlements of Ogbomoso region will have direct effects on microclimate of the region. According to Ephraim and Mbina 2014) greening offer improvement in air, water, and land resources by absorbing air pollutant, increasing water catchment and flood plain surfaces, and stabilizing soils.
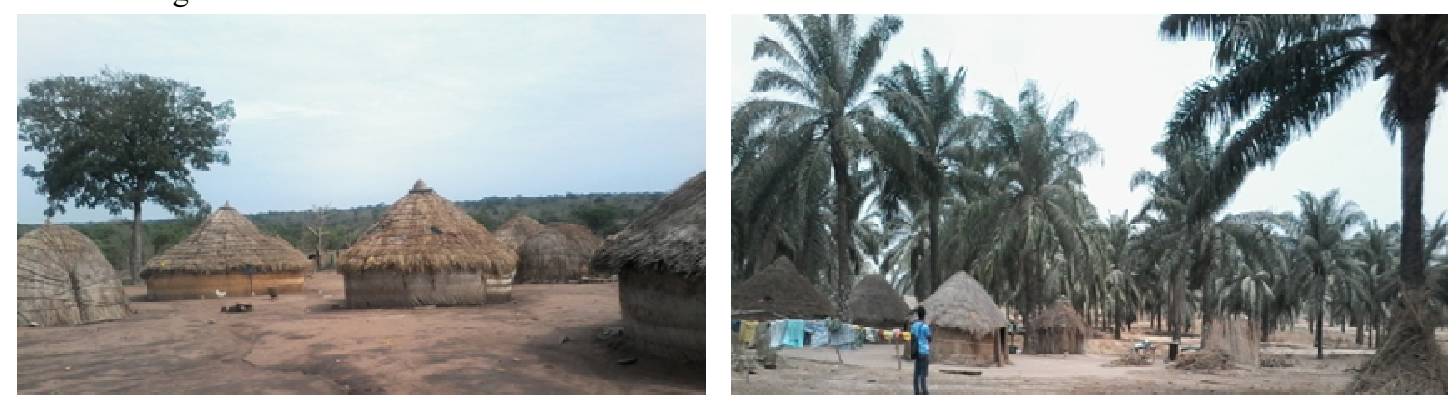

Plate 1 and 2: Air And Green Spaces at Gaa Alata, Surulere Local Government Area. Source: Author's Fieldwork, 2015

\section{9: Social Interaction between Fulani Nomads and Residents of Host Communities}

Table 6 summarizes residents' perception of social interaction of Fulani nomads in the study area. It is revealed from the analysis that the main forum of social interaction between the nomads and residents of host 
communities is participation in wedding ceremony, and naming ceremony with SII 4.04 each. This is followed by community association with SII 3.86 while involvement in political activities also recorded a significant proportion (SII, 3.06) of the responses. This suggests that social interaction between Fulani nomads and residents of host communities are mostly accepted by both parties although political activities remains is civic right of every Nigerian.

The opinion of sampled residents shows that social interaction on the basis of participation in cultural festival (SII, 2.97), conferment of chieftaincy title (SII, 2.06) and funeral rites (SII, 1.58) were perceived low. This suggests that although Fulani nomads engage in political activities, community association, naming and wedding ceremony they do so, as a matter of responsibility and may not socialize for leisure or luxury through funeral rites, chieftaincy or cultural festivals. The standard variation score recorded is 0.9066 while the variance is 0.8220 and coefficient of variation is $29.3 \%$. This implies that SII of the variables scatters around the mean value reducing the reliability of the mean value.

Table 6: Residents' Perception of Various Levels of Social Interaction Between Fulani Nomads and Residents of Host Communities

\begin{tabular}{|c|c|c|c|c|c|c|c|c|c|c|}
\hline \multirow[t]{2}{*}{ Social Interaction } & VH & $\mathbf{H}$ & IN & $\mathbf{L}$ & VL & \multirow[t]{2}{*}{ SWV } & \multirow[t]{2}{*}{ SII } & \multirow[t]{2}{*}{$\mathbf{X}$} & \multirow[t]{2}{*}{ D } & \multirow[t]{2}{*}{$\mathbf{D}^{2}$} \\
\hline & 5 & 4 & 3 & 2 & 1 & & & & & \\
\hline $\begin{array}{l}\text { Participation } \\
\text { association }\end{array}$ & 53 & 490 & 61 & 43 & - & 2496 & 3.86 & & 0.77 & 0.5929 \\
\hline Participation in wedding ceremony & 67 & 537 & 43 & - & - & 2612 & 4.04 & & 0.95 & 0.9025 \\
\hline Participation in naming ceremony & 67 & 537 & 43 & - & - & 2612 & 4.04 & & 0.95 & 0.9025 \\
\hline Participation in political activities & 114 & - & 287 & 250 & 46 & 1977 & 3.06 & 3.09 & -0.03 & 0.0009 \\
\hline Participation in cultural festival & 67 & 336 & - & - & 244 & 1923 & 2.97 & & -0.12 & 0.0144 \\
\hline Conferred with chieftaincy title & 12 & 1 & - & 634 & - & 1332 & 2.06 & & -1.51 & 2.2801 \\
\hline Participation in funeral rites & - & - & 67 & 244 & 336 & 1025 & 1.58 & & -1.03 & 1.0609 \\
\hline
\end{tabular}

Source: Author's Fieldwork, 2015

3.10: Residents' Perception of Cultural Adjustment of Fulani Nomads to the Host Communities

According to Wikipedia (2015), nomads of all kinds are facing problems in preserving their cultural heritage. As human achievements have advanced in recent times, bringing all people into greater contact with each other, the nomadic lifestyle has become endangered. Table 7 also presented that larger proportion of residents' opinion was recorded for cultural adjustments of Fulani nomads to the host communities through indigenous dress (CAI, 4.92), eating indigenous food (CAI, 4.77) and speaking indigenous language (CAI, 4.76). As a matter of fact, wearing of Fulani indigenous attire by the nomads is completely eroded even as eating of indigenous meals and speaking Fulani language are gradually going to extinction. Further analysis in Table 3 shows that the cultural adjustment indices for changing housing type to host communities' type and marriage rites are 3.88 and 3.30 in decreasing order. Also, the method and process of burying the dead (CAI, 1.87) by Fulani nomads remains unchanged. Factors upholding this cultural value could be deduced from the comment by a nomad in one the Focus Group Discussions that "culturally burial of the dead must be done at most two hours after the demise of the deceased. Also, our religious induction allows less than twenty four hours burying the dead. So there is no way we can keep the dead for long like many of the host communities do and commit sin." These are some of preserved cultural values of Fulani nomads in the study area. The variance of the mean is 1.1694 with standard deviation of 1.0814. This suggests that CAI variables scatter about the mean.

Table 7: Residents' Perception of Cultural Adjustment of Fulani Nomads to the Host Communities

\begin{tabular}{|c|c|c|c|c|c|c|c|c|c|c|}
\hline \multirow[t]{2}{*}{ Cultural Adjustment } & VS & $\mathbf{S}$ & IN & NS & NAA & \multirow[t]{2}{*}{ SWV } & \multirow[t]{2}{*}{ CAI } & \multirow[t]{2}{*}{$\mathbf{X}$} & \multirow[t]{2}{*}{ D } & \multirow[t]{2}{*}{$\mathrm{D}^{2}$} \\
\hline & 5 & 4 & 3 & 2 & 1 & & & & & \\
\hline $\begin{array}{l}\text { Fulani in this area wears } \\
\text { indigenous attire }\end{array}$ & 2985 & 200 & - & - & - & 3185 & 4.92 & & 1.00 & 1.0000 \\
\hline $\begin{array}{l}\text { Fulani in this area eats indigenous } \\
\text { Food }\end{array}$ & 2935 & 68 & - & 86 & - & 3089 & 4.77 & & 0.85 & 0.7225 \\
\hline $\begin{array}{l}\text { Fulani in this area speaks } \\
\text { indigenous language }\end{array}$ & 2950 & 28 & - & 100 & - & 3078 & 4.76 & 3.92 & 0.84 & 0.7056 \\
\hline $\begin{array}{l}\text { Fulani in this area are changing } \\
\text { their housing type to host } \\
\text { community type }\end{array}$ & 1635 & 36 & 243 & 43 & 25 & 2511 & 3.88 & & -0.04 & 0.0016 \\
\hline $\begin{array}{l}\text { Fulani in this area adopts the } \\
\text { community's marriage rites }\end{array}$ & 820 & 612 & 489 & 96 & 119 & 2136 & 3.30 & & -0.62 & 0.3844 \\
\hline Fulani in this area adopts the & 5 & - & 254 & 51 & 341 & 1210 & 1.87 & & -2.05 & 4.2025 \\
\hline
\end{tabular}


community's burial rites

Source: Author's Fieldwork, 2015

3.11: Residents' Perception of Incidences of Various Social Vices associated with Settlement of Fulani Nomads in the Past Five Years

Issues on social vices associated with settlement of Fulani nomads within the last five years are presented in Table 8 and 9. The result of findings reveals that there is a negative correlation between number of Fulani settlements and Fulani related crime incidence with correlation coefficient ( $r$ ) of -0.219 . Implying that in Ogbomoso region, as the number of Fulani settlements increases, crime rate decreases which is contrary to what is obtainable in most literature. However, Frieder (2003) opined that ethnicity and the status of being a foreigner are not a valuable factor for explaining crime. He further explained that specifically targeting migrants or foreigners for crime prevention is merely a social construct.

For more clarifications, further analysis on incidences of various social vices associated with settlement of Fulani nomads in Ogbomoso region was carried out. The output as summarized in Table 10 indicates that destruction of crops through grazing of cattle (SVI, 4.59) is the most perceived social vices. Other vices like robbery (SVI, 2.17), religious crisis (SVI, 1.97) loss of cattle lives (SVI, 1.88), loss of human lives (SVI, 1.88), ethnic clash (SVI, 1.84) and house burning (SVI, 1.66) are recorded to relatively less incidences in last five years within the study area. It could therefore be inferred that the nomads are not criminally inclined; they are only concerned about feeding their cattle well. The standard deviation is 0.9175 with a coefficient value of $13.1 \%$, implying that there is a scattered distribution about the mean value.

Table 8: Correlation of Fulani Nomadic settlements and Crime Incidence

\begin{tabular}{llcc}
\hline & & Number of Settlement & Crime Rate \\
\hline Number of settlement & Pearson correlation & 1 & -0.219 \\
& Sig (2-tailed) & & 0.544 \\
Crime Rate & Person correlation & -0.219 & 1 \\
& Sig.(2-tailed) & 0.544 & \\
\hline
\end{tabular}

Source: Author's Fieldwork, 2015

Table 9: Annual Reported Malicious Cases in the Study area (2006-2015)

\begin{tabular}{|lllll|}
\hline S/N & Year & Malicious Crime & $\begin{array}{l}\text { Settlement Position } \\
\text { Reported }\end{array}$ & $\begin{array}{l}\text { Compensation } \\
\text { Charged to Court }\end{array}$ \\
2 & 2006 & 3 & 3 & - \\
3 & 2007 & 2 & 2 & - \\
4 & 2008 & 1 & 1 & - \\
5 & 2009 & - & - & - \\
6 & 2010 & 6 & 6 & 6 \\
7 & 2011 & 8 & 2 & 13 \\
8 & 2012 & 13 & - & - \\
9 & 2013 & 15 & 15 & - \\
10 & 2014 & 10 & 10 & 16 \\
\hline & 2015 & 26 & 10 & 35 \\
\hline
\end{tabular}

Source: Author's Compilation from Police Record, 2015

Table 10: Perception on Incidences of Various Social Vices Associated with Settlement of Fulani Nomads in the Past Five Years

\begin{tabular}{|c|c|c|c|c|c|c|c|c|c|}
\hline \multirow[t]{2}{*}{ Social Vices } & $\mathbf{V S}$ & $\mathbf{S}$ & IN & NS & NAA & \multirow[t]{2}{*}{ SWV } & \multirow[t]{2}{*}{ SVI } & \multirow[t]{2}{*}{$\mathbf{D}$} & \multirow[t]{2}{*}{$\mathbf{D}^{2}$} \\
\hline & 5 & 4 & 3 & 2 & 1 & & & & \\
\hline Destruction of crops by grazing cattle & 2555 & 284 & - & 130 & - & 2969 & 4.59 & 2.16 & 4.2025 \\
\hline Robbery associated with Fulani migrants & - & 8 & 735 & 520 & 140 & 1430 & 2.17 & -0.26 & 0.0676 \\
\hline Loss of human lives during conflicts & - & 16 & 576 & 496 & 204 & 1292 & 2.00 & -0.43 & 0.1849 \\
\hline $\begin{array}{l}\text { Religious crisis between Fulani migrants } \\
\text { and host community }\end{array}$ & 20 & 16 & 513 & 536 & 201 & 1085 & 1.97 & -0.44 & 0.1936 \\
\hline Loss of cattle lives during conflicts & - & - & 477 & 508 & 234 & 1219 & 1.88 & -0.55 & 0.3025 \\
\hline $\begin{array}{l}\text { Ethnic clash between Fulani migrants and } \\
\text { host community }\end{array}$ & - & 28 & 285 & 668 & 211 & 981 & 1.84 & -0.59 & 0.3481 \\
\hline Burning of houses during conflicts & - & - & 285 & 478 & 313 & 1076 & 1.66 & -0.77 & 0.5929 \\
\hline
\end{tabular}

*Mean $=2.43$ 


\section{Source: Author's Fieldwork, 2015}

\subsection{Economic Impacts of Fulani Nomadic Settlement on Host Communities}

Blench (2010), analyses the economic interaction of herdsmen with residents of host communities to include exchange of dairy products for grain, access to local markets, among others. Against this background, this subsection presents the economic impacts of Fulani nomadic settlement on the host communities. Some of the impacts include the types economic activities carried out, goods and services demanded by Fulani nomads, as well as goods and services demanded by residents of host communities.

Tables 11, 12 and 13 summarize the level of significance of various economic impacts of Fulani nomadic settlements using Likert scale rating based on host communities residents perception. The index developed to measure this was tagged Economic Activities Index (EAI).

The results of analysis in Table 11 revealed that land cultivation and animal rearing are major economic activities with EAI (5.00) each. It is followed in decreasing order by hawking which has significant index of 4.80, while retail trade recorded 4.52 EAI indicating diversification of livelihood of the Fulani nomads in the study area. This suggests that agricultural practices such as animal rearing and land cultivation are the economic domain of the nomads while hawking and retail trade are the main economic diversification of Fulani nomads in Ogbomoso region. This is similar to assertion of Helen (2010) that diversification of livelihoods is important to the survival of pastoralists (or nomads), both for livelihoods that are related to livestock and those that are not. On the other hand, civil service, wholesale trade and artisan have negative EAI of 4.14, 3.09 and 3.12 respectively. The contributing factors to less engagement in civil service, whole trade and artisan may include lack of education and appropriate exposure. The variance is 0.59059 and standard deviation is 0.7684 .This implies that EAI variables scatter around the mean.

Further analysis in Tables 12 and 13 specifically shows the types of goods and services exchange between Fulani nomads and the residents of host communities. In comparism, the result of analysis shows that most goods and services demanded by residents of host communities from the nomads distinctively different from goods and services demanded by Fulani nomads from the host communities. For instance, there is a larger proportion purchase of dairy products like cheese (GSI, 4.93) and milk (GSI, 4.93) from the Fulani nomads. This is followed by purchase of cattle (GSI, 4.89) while a larger proportion of Fulani nomads demands tailoring services (GSI, 4.97), purchase of shoes (GSI, 4.86), with clothing and medicine (GSI 4.85) each. This implies that the economic sectors of the study area are only primary and tertiary.

It could also be observed that Fulani nomads demand less of services like bricklaying (GSI, 2.48), hairdressing (GSI, 3.40) and hair barbing GSI, 3.40) services from the residents. This is not surprising because traditional way of building houses and indigenous fashion taste reflecting in hair styles are very much accepted. Similarly, the residents demand less of shepherd services (-GSI, 2.47), purchase of farm produce (GSI, 2.81) and hunt games (GSI, 2.68) from the Fulani nomads. This establishes a fact that residents of host communities predominantly cultivate land, not necessarily interested in pastoral farming to a large extent. This expected since farming is the primary occupation in Ogbomoso region. Therefore, the economic development of the study area hinges on agriculture which includes land cultivation and pastoral farming.

Table 11: Involvement of Fulani nomads in Various Economic Activities

\begin{tabular}{|c|c|c|c|c|c|c|c|c|c|c|}
\hline \multirow{2}{*}{$\begin{array}{l}\text { Economic } \\
\text { Activities }\end{array}$} & VS & $\mathbf{S}$ & IN & NS & NAA & \multirow[t]{2}{*}{ SWV } & \multirow[t]{2}{*}{ EAI } & \multirow[t]{2}{*}{$X$} & \multirow[t]{2}{*}{ D } & \multirow[t]{2}{*}{$\mathbf{D}^{2}$} \\
\hline & 5 & 4 & 3 & 2 & 1 & & & & & \\
\hline Land cultivation & 3235 & - & - & - & - & 3235 & 5.00 & & 0.76 & 0.5776 \\
\hline Animal rearing & 3235 & - & - & - & - & 3235 & 5.00 & & 0.76 & 0.5776 \\
\hline Hawking & 3020 & - & - & 86 & - & 3106 & 4.80 & & 0.56 & 0.3136 \\
\hline Retail trade & 1810 & 1084 & - & 28 & - & 2922 & 4.52 & 4.24 & 0.28 & 0.0784 \\
\hline Artisan & 555 & 2104 & 03 & 18 & - & 2680 & 4.14 & & -0.10 & 0.0100 \\
\hline Civil service & 325 & - & 1569 & 98 & 10 & 1973 & 3.09 & & -1.15 & 1.3225 \\
\hline Wholesale trade & 1020 & 224 & - & 774 & - & 2018 & 3.12 & & -1.12 & 1.2544 \\
\hline
\end{tabular}

Source: Author's Fieldwork, 2015 
Table 12: Residents' Perception of Various Demanded Goods and Services by Fulani Nomads from the Host Communities

\begin{tabular}{|c|c|c|c|c|c|c|c|c|c|c|}
\hline \multirow{2}{*}{$\begin{array}{l}\text { Fulani Demanded Goods and } \\
\text { Services }\end{array}$} & VS & $\mathbf{S}$ & IN & NS & NAA & \multirow[t]{2}{*}{ SWV } & \multirow[t]{2}{*}{ GSI } & \multirow[t]{2}{*}{$\mathbf{X}$} & \multirow[t]{2}{*}{ D } & \multirow[t]{2}{*}{$\mathrm{D}^{2}$} \\
\hline & 5 & 4 & 3 & 2 & 1 & & & & & \\
\hline Tailoring in the community & 3190 & 16 & 09 & 04 & - & 3219 & 4.97 & & 0.49 & 0.2401 \\
\hline $\begin{array}{l}\text { Buying Shoes from the } \\
\text { community }\end{array}$ & 2900 & 220 & - & 24 & - & 3144 & 4.86 & & 0.38 & 0.1444 \\
\hline $\begin{array}{l}\text { Buying Clothing from the } \\
\text { community }\end{array}$ & 2900 & 208 & 09 & 24 & - & 3129 & 4.85 & & 0.37 & 0.1369 \\
\hline $\begin{array}{l}\text { Buying Medicine from the } \\
\text { community }\end{array}$ & 2900 & 212 & - & 28 & - & 3140 & 4.85 & & 0.37 & 0.1369 \\
\hline $\begin{array}{l}\text { Buying Food items from the } \\
\text { community }\end{array}$ & 2710 & 396 & - & 12 & - & 3118 & 4.82 & & 0.34 & 0.1156 \\
\hline Carpentry in the community & 2870 & 184 & 45 & 08 & 08 & 3115 & 4.81 & & 0.03 & 0.0009 \\
\hline $\begin{array}{l}\text { Grinding and milling of food } \\
\text { items in the community }\end{array}$ & 3005 & 12 & - & 86 & - & 3103 & 4.79 & & 0.31 & 0.0961 \\
\hline $\begin{array}{l}\text { Motorcycle repairs in the } \\
\text { community }\end{array}$ & 2990 & 24 & 86 & - & - & 3100 & 4.79 & 4.48 & 0.31 & 0.0961 \\
\hline Shoe repairs in the community & 2970 & 28 & 09 & 86 & - & 3093 & 4.78 & & 0.30 & 0.0900 \\
\hline $\begin{array}{l}\text { Buying Animal drug from the } \\
\text { community s }\end{array}$ & 2645 & 376 & 9 & 38 & 2 & 3070 & 4.75 & & 0.27 & 0.0729 \\
\hline Hairdressing in the community & 1395 & 28 & 195 & 578 & 07 & 2203 & 3.40 & & -1.08 & 1.1664 \\
\hline Hair barbing in the community & 1395 & 28 & 195 & 578 & 07 & 2203 & 3.40 & & -1.08 & 1.1664 \\
\hline Tailoring in the community & 3190 & 16 & 09 & 04 & - & 3219 & 4.97 & & 0.49 & 0.2401 \\
\hline $\begin{array}{l}\text { Buying Building materials } \\
\text { from the community }\end{array}$ & 2645 & 372 & - & 44 & 3 & 3064 & 4.74 & & 0.26 & 0.0676 \\
\hline $\begin{array}{l}\text { Buying Farm tools from the } \\
\text { community }\end{array}$ & 2650 & 316 & 66 & 28 & 02 & 3062 & 4.73 & & 0.25 & 0.0625 \\
\hline $\begin{array}{l}\text { Buying Books and stationeries } \\
\text { from the community }\end{array}$ & 2860 & 88 & - & 78 & 14 & 3040 & 4.69 & & 0.21 & 0.0441 \\
\hline Hairdressing in the community & 1395 & 28 & 195 & 578 & 07 & 2203 & 3.40 & & -1.08 & 1.1664 \\
\hline Hair barbing in the community & 1395 & 28 & 195 & 578 & 07 & 2203 & 3.40 & & -1.08 & 1.1664 \\
\hline Brick laying in the community & 25 & 372 & 501 & 652 & 56 & 1606 & 2.48 & & -2.00 & 4.0000 \\
\hline
\end{tabular}

Source: Author's Fieldwork, 2015

Table 13: Residents' Perception of Various Demanded Goods and Services by Residents of Host Communities from the Fulani Nomads

\begin{tabular}{|c|c|c|c|c|c|c|c|c|c|c|}
\hline \multirow{2}{*}{$\begin{array}{c}\text { Community Demanded Goods } \\
\text { and Services }\end{array}$} & VS & $\mathbf{S}$ & IN & NS & NAA & \multirow[t]{2}{*}{ SWV } & \multirow[t]{2}{*}{ GSI } & \multirow[t]{2}{*}{$\mathbf{X}$} & \multirow[t]{2}{*}{$\mathbf{D}$} & \multirow[t]{2}{*}{$\mathbf{D}^{2}$} \\
\hline & 5 & 4 & 3 & 2 & 1 & & & & & \\
\hline $\begin{array}{l}\text { Buying Cheese from Fulani } \\
\text { nomads }\end{array}$ & 3020 & 172 & - & - & - & 3192 & 4.93 & & 1.11 & 1.2321 \\
\hline Buying milk from Fulani nomads & 3020 & 172 & - & - & - & 3192 & 4.93 & & 1.11 & 1.2321 \\
\hline Buying cattle from Fulani nomads & 2980 & 172 & 3 & 14 & - & 3169 & 4.89 & & 1.07 & 1.1449 \\
\hline Buying Herbs from Fulani nomads & 2690 & 261 & 44 & - & - & 2995 & 4.59 & & 0.77 & 0.5929 \\
\hline Buying birds from Fulani nomads & 1255 & 440 & 129 & 486 & - & 2310 & 3.57 & 3.82 & -0.25 & 0.0625 \\
\hline $\begin{array}{l}\text { Spiritual consultation from Fulani } \\
\text { nomads }\end{array}$ & 65 & 1268 & 951 & - & - & 1184 & 3.53 & & -0.29 & 0.0841 \\
\hline $\begin{array}{l}\text { Buying farm produce from Fulani } \\
\text { nomads }\end{array}$ & 215 & 204 & 870 & 526 & - & 1552 & 2.81 & & -1.01 & 1.0201 \\
\hline $\begin{array}{l}\text { Buying hunt games from Fulani } \\
\text { nomads }\end{array}$ & 15 & 376 & 735 & 610 & - & 1721 & 2.68 & & -1.14 & 1.2996 \\
\hline $\begin{array}{l}\text { Shepherd service from Fulani } \\
\text { nomads }\end{array}$ & - & - & 1044 & 504 & 47 & 1595 & 2.47 & & -1.35 & 1.8225 \\
\hline
\end{tabular}

\section{Source: Author's Fieldwork, 2015}

3.13 Variation in the Impacts of Fulani Nomadic settlements across Ogbomoso Region

Despite some commonalities in the impacts of Fulani nomadic settlements in each host community, some 
variations exist. It is therefore important to analyze the variations observed across the study area. However, the focus is centered on variation in urban local government areas and rural local government areas. On this premise, ANOVA test performed reveals that residents of different local government areas do not perceive the impacts of Fulani nomadic settlements the same way.

The probability values for only few impacts indicate that there is spatial variation in the perception of residents across the five local government areas. The impacts concerned are social interaction impact and biophysical impacts (Table14). Also, the variation of these two impacts are confidently significant at $95 \%$ level with the means of the same independent variable not the same for different local government areas. This implies that, characteristics of urban and rural (particularly the population size and land availability) of Ogbomoso region will introduce variation in social interaction and environmental impacts of Fulani informal settlements.

On the other hand, there is no spatial variation in the perception of residents across the five local government areas on such impacts like types of goods and services demanded, cultural adjustment, economic activity, social vices, and shared facilities with probability values of $1.257,0.385,0.302,0.094$, and 0.00 respectively. It could be inferred that the impacts of types of goods and services exchanged between the nomads and residents of host communities, economic activities, cultural adjustment, social vices, and shared facilities are not influenced by urban or rural characteristics.

Table 14: Analysis of Variance: Impacts of Fulani Informal settlements within Ogbomoso Region

\begin{tabular}{|c|c|c|c|c|c|c|}
\hline Major impacts & Variations & $\begin{array}{l}\text { Sum of } \\
\text { Squares }\end{array}$ & DF & $\begin{array}{l}\text { Mean } \\
\text { Square }\end{array}$ & $\mathbf{F}$ & $\begin{array}{l}\text { Probability } \\
\text { Value }\end{array}$ \\
\hline $\begin{array}{l}\text { Types of goods and } \\
\text { services exchanged }\end{array}$ & $\begin{array}{l}\text { Between Groups } \\
\text { Within Groups } \\
\text { Total }\end{array}$ & $\begin{array}{l}3684.996 \\
8314.790 \\
11999.786\end{array}$ & $\begin{array}{l}4 \\
642 \\
646\end{array}$ & $\begin{array}{l}296.250 \\
10.685\end{array}$ & 27.450 & 1.257 \\
\hline $\begin{array}{l}\text { Social Interaction } \\
\text { Impact }\end{array}$ & $\begin{array}{l}\text { Between Groups } \\
\text { Within Groups } \\
\text { Total }\end{array}$ & $\begin{array}{l}156.973 \\
1165.445 \\
1322.418\end{array}$ & $\begin{array}{l}4 \\
642 \\
646\end{array}$ & $\begin{array}{l}39.243 \\
1.723\end{array}$ & 22.776 & 0.000 \\
\hline Economic Activity & $\begin{array}{l}\text { Between Groups } \\
\text { Within Groups } \\
\text { Total }\end{array}$ & $\begin{array}{l}165.508 \\
2169.355 \\
2334.863\end{array}$ & $\begin{array}{l}4 \\
642 \\
646\end{array}$ & $\begin{array}{l}41.376 \\
3.379\end{array}$ & 12.245 & 0.302 \\
\hline Social Vices Impact & $\begin{array}{l}\text { Between Groups } \\
\text { Within Groups } \\
\text { Total }\end{array}$ & $\begin{array}{l}186.399 \\
3979.528 \\
4165.927\end{array}$ & $\begin{array}{l}4 \\
642 \\
646\end{array}$ & $\begin{array}{l}46.599 \\
6.200\end{array}$ & 7.516 & 0.094 \\
\hline Shared Facilities Impact & $\begin{array}{l}\text { Between Groups } \\
\text { Within Groups } \\
\text { Total }\end{array}$ & $\begin{array}{l}164.821 \\
2548.572 \\
2713.393\end{array}$ & $\begin{array}{l}4 \\
642 \\
646\end{array}$ & $\begin{array}{l}41.205 \\
5.961\end{array}$ & 6.912 & 0.060 \\
\hline Biophysical Impact & $\begin{array}{l}\text { Between Groups } \\
\text { Within Groups } \\
\text { Total }\end{array}$ & $\begin{array}{l}54.264 \\
1511.887 \\
1566.151\end{array}$ & $\begin{array}{l}4 \\
642 \\
646\end{array}$ & $\begin{array}{l}13.565 \\
2.354\end{array}$ & 5.762 & 0.037 \\
\hline $\begin{array}{l}\text { Cultural Adjustment } \\
\text { Impact }\end{array}$ & $\begin{array}{l}\text { Between Groups } \\
\text { Within Groups } \\
\text { Total }\end{array}$ & $\begin{array}{l}72.076 \\
10.685 \\
11.665\end{array}$ & $\begin{array}{l}4 \\
642 \\
646\end{array}$ & $\begin{array}{l}18.019 \\
6.828\end{array}$ & 2.639 & 0.385 \\
\hline
\end{tabular}

*Mean difference significant at 0.95 level.

Source: Author's Fieldwork, 2015

\section{Recommendations}

Based on the findings of this research, it is observed that formalizing Fulani settlement cannot erupt overnight. Therefore, the recommendation of this study is made as strategic planning. The strategic plan should have the backup of both the institutional and legal frameworks of Oyo State Government, also it should involve stating of attainable goal and measurable objectives with a time target. The institutional and legal frameworks must recognize the role of planners and involve full participation of Fulani Nomads. The strategic plan should evolve an encompassing vision, goals and objectives for the realization of the vision. The vision should revolve around a renown united and functional agro-based region in Nigeria which is sustainably dynamic and guided by appropriate statutory bodies. This can be achieved by formulating appropriate Nomadic policy through establishment of Ogbomoso Region Nomadic Development Authority as well as Preparation of Ogbomoso Region Nomadic Degree. Land can be secured and reserved for grading this will undoubtedly ban scavenging and free-ranging animal gazing This paper also suggest adoption of indigenous knowledge of environmental management. 


\section{Conclusion}

The study concludes that the impacts of Fulani nomads' informal settlement on host communities within Ogbomoso region have adverse implications on the environment. At the same time, cattle production of the nomads is a potential development of a regional specialization of the study area. The study therefore believes if the provided recommendation can be used by decision makers, Ogbomoso region will be a pace setter in regional development.

\section{References}

Blench R. (2010): Conflict between Pastoralists and Cultivators in Nigeria, Kay William Educational Foundation Cambridge, Available onlinewww.rogerbtench.infor/RBOP.htm

Deda, L. (2003): The New Housing Market in Tirana, S. Lowe et al. (eds.), Housing Change in East and Central Europe: Integration or Fragmentation?, Ashgate Publishing Limited Aldershot, United Kingdom.

Dregne H., Kassas M., and Rosanov B. (1991): A New Assessment of the World Status of Desertification, Desert Contribution Journal. Bulletin Vol. 20, pp 6-29.

Frieder D. (2003):Migration and ethnic minorities in Germany: impacts on youth crime, juvenile justice and youth imprisonment, University of Greifswald, Germany.

Helen B.(2010): Pastoralism Demographics, Settlement and Service Provision in the Horn and East Africa: Transformation and Opportunities, Overseas Development Institute, London, United Kingdom.

Huchzermeyer, M. (2004): Unlawful Occupation: Informal Settlements and Urban Policy in South Africa and Brazil, Trenton, Africa World Press Inc, South Africa.

Isah M. (2014): No Retreat No Surrender Conflict For Survival Between Fulani Pastoralists And Farmers In Northern Nigeria, European Scientific Journal, Vol.8 No.1.

Jamala G., Boni P., Abraham P., and Teru C. (2012): Evaluation of Environmental and Vulnerability Impact of Bushing Burning in Southern Guinea Savanna of Adamawa State, Nigeria, American Journal of Experimental Agriculture, Vol.2(3), pp 359-369.

Kramer, M. (2006): Dispossessed: Life in Our World's Urban Slums, Orbis Books, New York.

Manal E. and Christian A. (1998): A Shelter of their Own: Informal Settlement Expansion in Greater Cairo and Government Responses, Environmental and Urbanization, Vol. 10, No.1.

Morakinyo K. Ogunrayewa M. Koleosho B. and Adenubi O. (2012): Urban Slums as Spatial Manifestation of Urbanization in Sub-Saharan Africa: A case study of Ajegunle Slum Settlement Lagos, Developing Country Studies, Vol.2, No. 11.

Olayoku P. (2014): Trends and Patterns of Cattle Grazing and Rural Violence in Nigeria (2006- 2014), IFRANIGERIA Working papers series, No. 34.

Rafis A. (2013): Globalization of Migration; What Is Modern World Can Learn from Nomadic Culture, http: UNchronicle.un.org/article/globalization-migration-what-world -can-learn- nomadic-cultures.

Wilbard J. and Volker K. (2001): Informal Land Management in Tanzania and the Misconception about Illegality, a paper presented at EST/N-Aerus Annual Workshop "coping with Informality and Illegality in Human Settlement held at Leuven and Brussels, May 23-26, 2001. 